\title{
Giuseppe Eusepi: a courageous and cheerful countenance for the ages
}

\author{
Richard E. Wagner ${ }^{1}$
}

๑ Springer Science+Business Media, LLC, part of Springer Nature 2020

Giuseppe Eusepi died at age 71 in Rome on the fourth of October 2020. For those of you who knew Giuseppe and who experienced his keen intellect along with his kindness and cheerfulness, a reason to pause and note his passing will be evident. For those readers who never had the opportunity to know him, I should like to call briefly to your attention the reasons why you too should appreciate Giuseppe's life.

Giuseppe's last publication was in volume 183 of Public Choice and was titled: "From Subjectivism to Constitutionalism: The Intellectual Journey of James M. Buchanan through his Italian Heroes." That issue of Public Choice contains papers presented at a conference in October 2019 celebrating what would have been Buchanan's 100 ${ }^{\text {th }}$ birthday. In his contribution to that celebration, Giuseppe explored the central ideas of some of the principal Italian figures whose work figured prominently in Buchanan's scholarly development. Remember, it was Buchanan who brought to English readers the rich Italianate vein of conceptual ideas relevant for public economics that lay neglected within English-language writings. Among other things, Giuseppe explains that much scholarly value can be extracted from that Italian vein. While Giuseppe died with many projects still percolating inside his active imagination, the 2020 paper marks a fitting end to his scholarly career all the same.

Origins are nearly impossible to date because precursors to what you nominate as an origin nearly always can be found. Machiavelli, for instance, could reasonably be located as the origin of public choice, but he had precursors. With respect to our contemporary world, Antonio de Viti de Marco was Giuseppe's candidate for dating the origin of public choice, and on that conclusion I certainly would concur. In 1888, De Viti published a small book that in translation would have been titled The Theoretical Character of Public Finance. There, de Viti showed how public finance might be transformed from a normative to an explanatory field of study. For instance, rather than economists advising governments about how progressive an income tax should be, de Viti counseled economists to treat tax codes as themselves objects of explanation. Alternatively, rather than pronouncing on an optimal amount of educational spending, de Viti would have counseled exploration into how different institutional and organizational arrangements influenced actual budgetary outcomes.

Richard E. Wagner

rwagner@gmu.edu

1 Fairfax, VA, USA 
De Viti unleashed what became a strong Italian tradition in public economics that, after flourishing into the 1930s, went into near quiescence in the aftermath of war and Fascism, only to be reborn as public choice in the 1960s, and with James Buchanan being at the center of that rebirth. Giuseppe Eusepi was an exemplary and tireless carrier of de Viti's Italianate orientation toward public economics into our times, as his final paper illustrates. And those labors Giuseppe performed under conditions of extreme stress and disability.

Giuseppe was blind, as those of you who knew him know. To start, he was born in 1949 with a congenital form of glaucoma. At age four he lost his right eye in an accident, and then lost his left eye in another accident at age 13. Living with those handicaps, Giuseppe persevered admirably through his school curricula, graduating with his doctorate from the Sapienza University of Rome in 1974. Along the way, he met his wife to be Maria Delle Grotti, who was a student of English literature. Not only did Maria support Giuseppe's acquisition of English after he had studied French within his regular curriculum, but she and Giuseppe became inseparable for the remainder of their days together.

About ten years ago, Giuseppe came down with Parkinson's disease which continually intensified through the remainder of his life, manifesting in interacting cycles of growing dyskinesias and heavier doses of medication that accompanies the disease. In July 2020 he was diagnosed with cancer that metastasized quickly until the end.

Giuseppe attended the meetings of the Public Choice Society frequently where he was active in presenting papers and discussing the work of other participants. Moreover, he established the European Center for the Study of Public Choice in Rome in 1999. The ECSPC featured such public choice luminaries as Beat Blankart, Geoffrey Brennan, Lars Feld, Bruno Frey, Alan Hamlin, Gebhard Kirchgassner, Dennis Mueller, Charles Rowley, Friedrich Schneider and Viktor Vanberg. Through the ECSPC, Giuseppe promoted the spread of public choice ideas by way of the nearly annual conferences he organized, and with those conferences resulting in a continual parade of books and special issues of journals.

A few years ago, I closed a paper I wrote about Gordon Tullock this way: "Gordon Tullock was the kindest and gentlest man I have ever known." Now I have known two men about whom I can declare to be the kindest and gentlest men I have ever known. Giuseppe Eusepi, Requiescat in pace.

Publisher's Note Springer Nature remains neutral with regard to jurisdictional claims in published maps and institutional affiliations. 